\title{
Nevrologer er bedre enn sitt rykte
}

\author{
Jeg er med i en trivelig klubb, kalt Ad libido. Fellesnevneren er at medlemmene tok doktorskolen i Oslo \\ sammen. Senere har vi valgt høyst forskjellige fagfelter innen medisinen, de fleste er i spesialisthelse- \\ tjenesten. Klubbmøtene er preget av høylytte diskusjoner - fra seriøse debatter til det rene vrøvl.
}

En gjenganger er det jevnt voksende helsebyråkratiet, der noen skrotinger med liten innsikt i den kliniske hverdag helt ukritisk har adoptert næringlivstankegangen. Vi får til stadighet høre at vi må øke «produksjonen». De ser altså på våre pasienter som produkter! Er det rart vi gremmes?

Klubbens eneste helsebyråkrat forsøker å forsvare byråkratiet ved å hevde at ethvert syttendemaitog må ha en syttendemaikomité. Analogien blir naturligvis latterliggjort, og vi forklarer ham at komiteen jo er blitt lengre enn selve toget!

Utover de sene klubbkvelder synker saklighetsnivået, og fordommene florerer fritt. Og jo mindre innsikt, desto sterkere mening. Kolleger utenfor eget fagfelt er som oftest uten forstand. Den store ideolog Fredrik Stabel siteres ofte: «Fornuften er en ensom ting. Hvor ofte er man ikke alene om å stole på den.» Toleranse er oppskrytt. At kardiologer kan vie hele sitt doktorliv til den slaskete hjertemuskelen, er ikke til å forstå. Dessuten, alle dermatologer er overfladiske. Det beste eksemplet på en dobbeltblind studie er to ortopeder som skal tolke et EKG. At medlemmene huset så mange fordommer også mot nevrologer, var for meg noe overraskende.

\section{Er nevrologer humørløse?}

Nevrologer blir sett på som noen selvhøytidelige, nerdete, sidrumpede og tvangspregede hengehuer. Noen er så intellektuelle at de går med sløyfe. Nevrologisk humor blir ansett som en selvmotsigelse. Følgende gjettelek er en favoritt: «Hvordan ser du forskjell på en nevrologisk pasient og en nevrolog som kommer bortover sykehusgangen?» «På pasienten henger den ene munnviken, på nevrologen henger begge.»

\section{Er nevrologer trege?}

Flere var av den oppfatning at de som velger nevrologi, gjør det fordi de er sen- drektige, arbeidsskye og misliker øyeblikkelig hjelp. Det hevdes at en hastesak i nevrologien tar 3-4 uker.

Her har ikke medlemmene fulgt med i timen, dvs. omtrent som i studietiden. Vi kan i dag behandle mange nevrologiske tilstander effektivt ved rask inngripen, for eksempel ved migreneanfall og status epilepticus. For ikke å snakke om trombolytisk behandling av slag - der vi helst smir mens hjernen er varm.

\section{Har MR gjort nevrologene overflødige?}

Etter at vi fikk MR mente medlemmene at nevrologene kunne legge bort reflekshammer og sikkerhetsnål. «Dere kan heller knipse av et MR-bilde.» Intet er mer galt! Svært mange nevrologiske tilstander lar seg ikke detektere på MR-undersøkelse, og fortsatt er en god sykehistorie kombinert med en grundig nevrologisk undersøkelse selve gullstandarden i all nevrologisk diagnostikk.

\section{«... smir mens \\ hjernen er varm»}

\section{Er nevrologer bare opptatt av diagnostikk?}

Medlemmene synes å være av den oppfatning at nevrologer er fornøyde bare de kan stille en diagnose og at det stadig ikke finnes noen form for behandling. Jeg siterer kirurgen i klubben: «Mens vi kirurger tar oss av den kurative virksomheten, får dere nevrologer nøye dere med å lindre og trøste.»

Den terapeutiske nihilisme som tidligere preget nevrologien, synes således å være en svært seiglivet myte. Det skal innrømmes at mange nevrologiske sykdommer er av kronisk art, men ved mange av disse har vi i dag gode symptomdempende midler. Og palliativ medisin bør man ikke kimse av. Dessuten - det er mye god behandling i god diagnostikk!

\section{Har nevrologiske sykdommer lav prestisje?}

Til tross for at hjernen som kjent er vårt viktigste organ, havner nevrologiske sykdommer langt nede i sykdomshierarkiet. Slike sykdommer er ikke mye å skryte av, kanskje bortsett fra migrene, som anses å være «finere» enn simpel spenningshodepine. Men det finnes sykdommer med enda lavere prestisje. Jeg har derfor en viss sympati for proktologen i klubben, som klager over at hemoroidene alltid kommer bakerst.

\section{Konklusjon}

En av Bob Dylans dypsindigheter er «the times they are a-changin». Ikke alle har fått med seg dette. Nevrologien har gjennomgått store endringer de siste 2-3 tiårene, og parallelt med denne utviklingen er det kommet en ny og spenstig generasjon nevrologer der det er svært langt mellom hengehuene.

\section{Karl 0. Nakken}

karl.otto.nakken@ous-hf.no

Klinikk for kirurgi og nevrofag

Oslo universitetssykehus

Karl Otto Nakken (f. 1945) er spesialist

i nevrologi og seksjonsoverlege.

Ingen oppgitte interessekonflikter.

Mottatt 23.10. 2011 og godkjent 3.11. 2011. Medisinsk redaktør Erlend Hem. 